Corrigendum

\title{
Corrigendum to "Metalloproteinases and Their Tissue Inhibitors in Comparison between Different Chronic Pneumopathies in the Horse"
}

\author{
Ann Kristin Barton, ${ }^{1}$ Tarek Shety, ${ }^{1,2}$ Angelika Bondzio, ${ }^{3}$ Ralf Einspanier, ${ }^{3}$ \\ and Heidrun Gehlen ${ }^{1}$ \\ ${ }^{1}$ Equine Clinic, Veterinary Faculty, Freie Universitaet Berlin, Oertzenweg 19b, 14163 Berlin, Germany \\ ${ }^{2}$ Animal Medicine Department, Faculty of Veterinary Medicine, Zagazig University, Zagazig, Egypt \\ ${ }^{3}$ Institute of Veterinary Biochemistry, Veterinary Faculty, Freie Universitaet Berlin, Oertzenweg 19b, 14163 Berlin, Germany \\ Correspondence should be addressed to Ann Kristin Barton; ann-kristin.barton@fu-berlin.de \\ Received 19 November 2017; Accepted 27 November 2017; Published 11 December 2017 \\ Copyright (C) 2017 Ann Kristin Barton et al. This is an open access article distributed under the Creative Commons Attribution \\ License, which permits unrestricted use, distribution, and reproduction in any medium, provided the original work is \\ properly cited.
}

In the article titled "Metalloproteinases and Their Tissue Inhibitors in Comparison between Different Chronic Pneumopathies in the Horse" [1], there was a missing affiliation for the second author. The revised authors' list and affiliations are shown above.

\section{References}

[1] A. K. Barton, T. Shety, A. Bondzio, R. Einspanier, and H. Gehlen, "Metalloproteinases and their tissue inhibitors in comparison between different chronic pneumopathies in the horse," Mediators of Inflammation, vol. 2015, Article ID 569512, 9 pages, 2015 


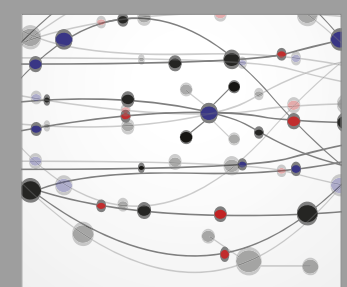

The Scientific World Journal
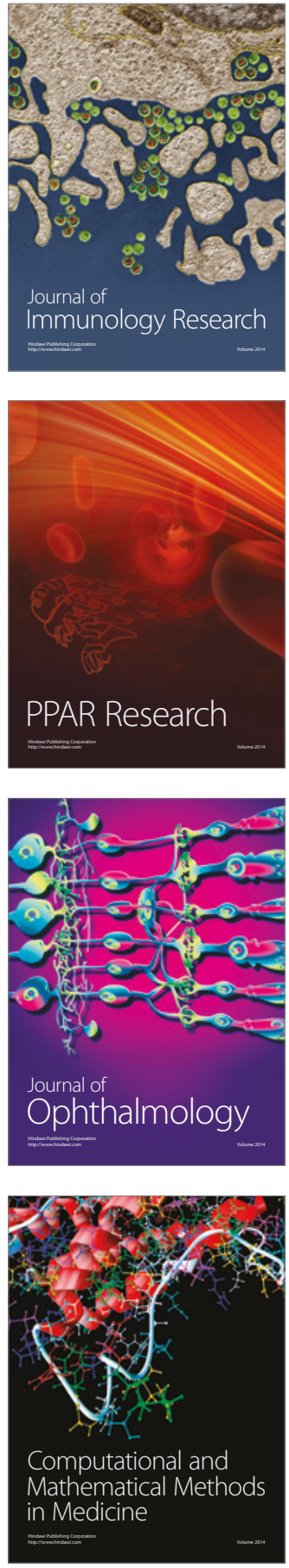

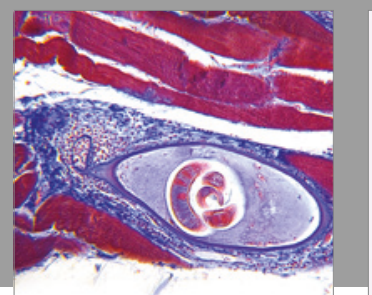

Gastroenterology Research and Practice
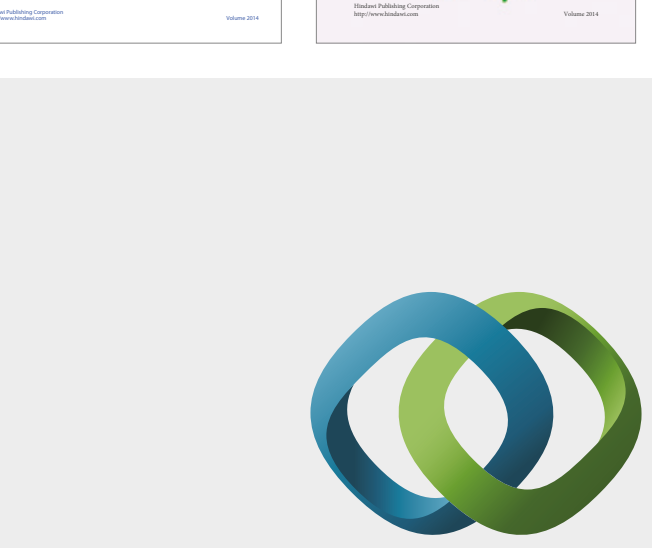

\section{Hindawi}

Submit your manuscripts at

https://www.hindawi.com
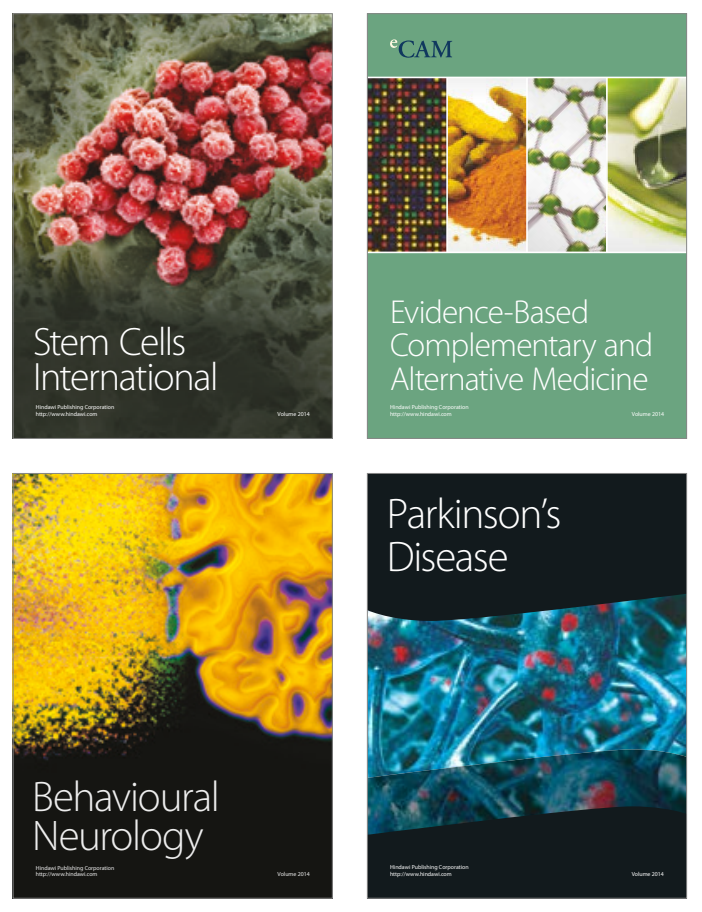
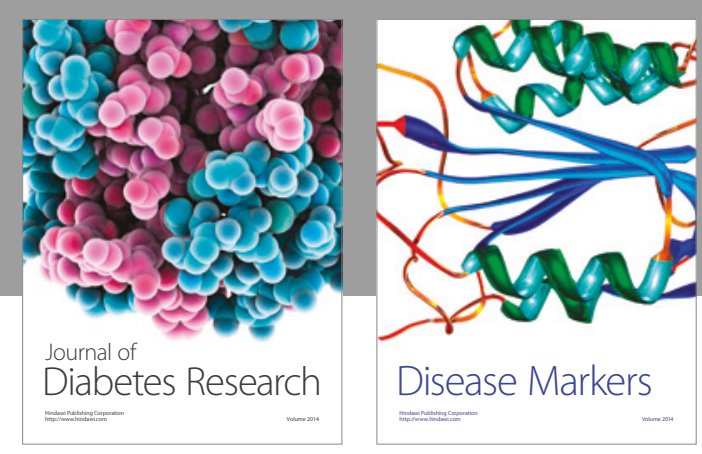

Disease Markers
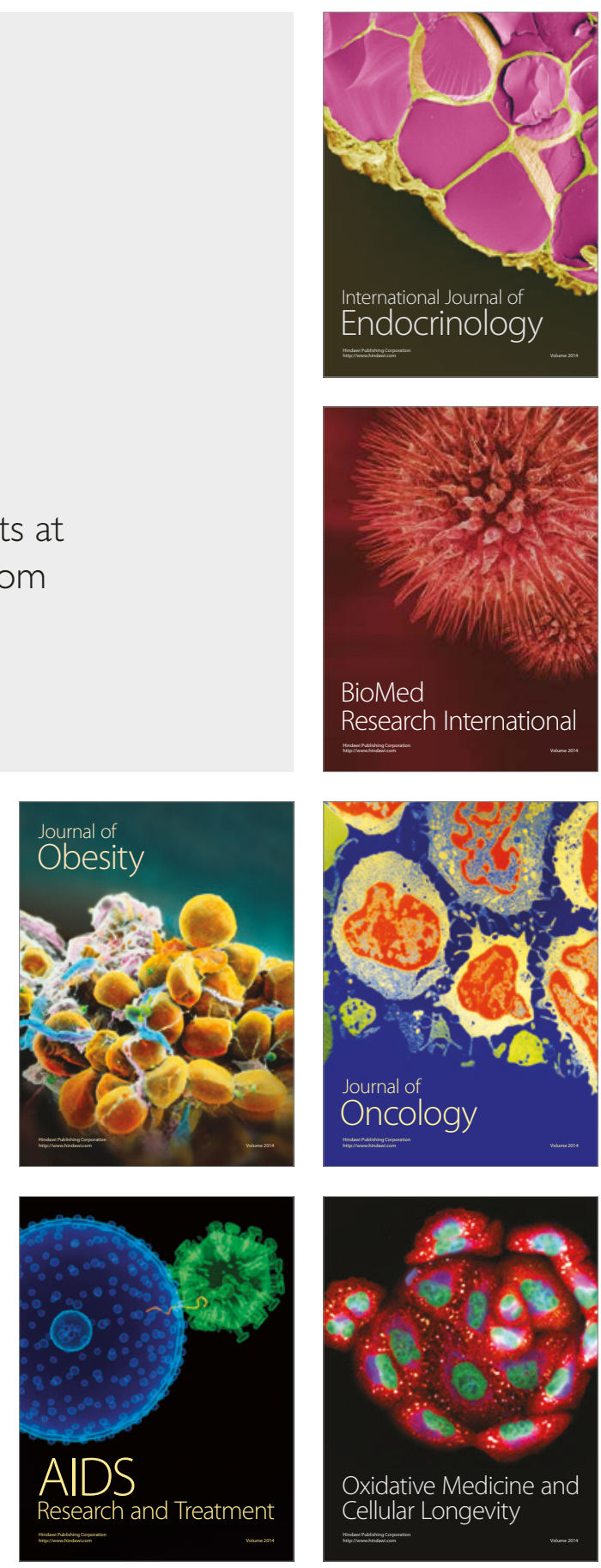